\title{
Changes in Myocardial Electrolytes and Ventricular Fibrillation Threshold Induced by Alcohol Feeding in Laboratory Rats
}

\author{
S.M. Khedun, M.M.E.D.Sc., W.P. Leary, D.Sc., \\ G.J. Lockett, M.Sc., and B. MaharaJ, F.C.P.
}

\begin{abstract}
SUMmary
Three groups of rats were studied in an investigation to determine the influence of alcohol on myocardial electrolytes and the ventricular fibrillation threshold (VFT) levels. Drinking water was provided ad libitum; the control group received water while the other 2 groups drank a water-ethanol solution, constituted in a ratio of $75: 25$, for periods of 3 and 9 months, respectively. Two rats from each of the experimental groups, together with a control rat were killed on each experimental day. One heart was studied on the Langendorff preparation and the other used for tissue electrolyte analysis. The mean myocardial $\mathrm{Mg}^{2+}$ levels $(233 \pm 28 \mu \mathrm{g} / \mathrm{g}$ vs $148 \pm 23 \mu \mathrm{g} / \mathrm{g}$ and $233 \pm 28 \mu \mathrm{g} / \mathrm{g}$ vs $107 \pm$ $15 \mu \mathrm{g} / \mathrm{g} ; \mathrm{p}<0.0001), \mathrm{K}^{+}$levels $(3260 \pm 437 \mu \mathrm{g} / \mathrm{g}$ vs $1779 \pm 312 \mu \mathrm{g} / \mathrm{g}$ and $3260 \pm 437 \mu \mathrm{g} / \mathrm{g}$ vs $1195 \pm 205 \mu \mathrm{g} / \mathrm{g} ; \mathrm{p}<0.0001)$ and $\mathrm{Zn}^{2+}$ levels $(32.7 \pm$ $6.8 \mu \mathrm{g} / \mathrm{g}$ vs $14.0 \pm 4 \mu \mathrm{g} / \mathrm{g}$ and $32.7 \pm 6.8 \mu \mathrm{g} / \mathrm{g}$ vs $4.2 \pm 3.4 \mu \mathrm{g} / \mathrm{g} ; \mathrm{p}<0.0001)$ were significantly lower in alcohol fed rats than the controls. In addition, a significant fall in the mean VFT levels $(10.1 \pm 1.94 \mathrm{~mA}$ vs $6.27 \pm$ $2.17 \mathrm{~mA}, \mathrm{p}<0.001$ ) was noted in rats given water: alcohol solution for 9 months. This study reveals that chronic exposure to alcohol induces a deficiency of myocardial $\mathrm{Mg}^{2+}, \mathrm{K}^{+}$and $\mathrm{Zn}^{2+}$, and an increase in myocardial irritability in laboratory rats.
\end{abstract}

\section{Additional Indexing Words :}

Alcohol Magnesium deficiency Potassium deficiency Zinc deficiency Ventricular fibrillation threshold levels Langendorff preparation

$\mathrm{M}$ AGNESIUM, a biologically essential cation, has recently become the focus of increasing research and interest with regard to the role of its depletion in cardiovascular pathophysiology. $\mathrm{Mg}^{2+}$ deficiency is often overlooked as a cause of cardiac arrhythmias. Numerous studies have documented an increased incidence of ventricular tachyarrhythmias of various types, ${ }^{1)-4)}$ including digitalis intoxication, ${ }^{5 /}$ drug induced torsades de pointes, ${ }^{6}$ )

\footnotetext{
From the Department of Clinical and Experimental Pharmacology, University of Natal Medical School, Durban, South Africa.

Received for publication June 13, 1990.

Accepted September 19, 1990.
} 
multifocal atrial tachycardia ${ }^{7}$ and atrial fibrillation ${ }^{8)}$ with $\mathrm{Mg}^{2+}$ deficiency. Since alcohol is known to produce $\mathrm{Mg}^{2+}$ depletion in serum, ${ }^{91}$ a study was designed to determine the effects of alcohol on myocardial electrolytes and the ventricular fibrillation threshold levels in laboratory rats.

\section{Materials and Methods}

Sixty male rats of the University of Natal inbred Wistar strain, weighing 250-300 g, were individually ear-marked and randomly assigned to 3 groups of 20. They were housed in stainless steel cages with plastic bottoms. Drinking water was provided ad libitum. The control group received water alone, while the other 2 groups received a water-ethanol solution, constituted in a ratio of $75: 25$, for periods of 3 and 9 months, respectively. All the animals were given a diet of commercial rat cubes (Epol); the mineral constituents of which appear in Table I.

After 3 months, 10 control rats and 20 alcohol-fed rats were sacrificed; the remaining control and alcohol-fed rats were sacrificed 6 months later.

Table I. Mineral Constituents of United Epol Rat Cubes

\begin{tabular}{l|c}
\hline \multicolumn{1}{c|}{ Minerals } & \\
\hline Calcium & $10.63 \mathrm{~g} / \mathrm{kg}$ feed \\
Phosphorus & $7.56 \mathrm{~g} / \mathrm{kg}$ \\
Magnesium & $1.42 \mathrm{~g} / \mathrm{kg}$ \\
Sodium & $2.5 \mathrm{mg} / \mathrm{kg}$ \\
Potassium & $4.43 \mathrm{mg} / \mathrm{kg}$ \\
Manganese & $17.60 \mathrm{mg} / \mathrm{kg}$ \\
Manganese Sulphate & $104.80 \mathrm{mg} / \mathrm{kg}$ \\
Zinc Sulphate & $429.60 \mathrm{mg} / \mathrm{kg}(172 \mathrm{mg} \mathrm{Zn} / \mathrm{kg})$ \\
Copper Sulphate & $838.20 \mathrm{mg} / \mathrm{kg}$ \\
Cobalt Sulphate & $10.50 \mathrm{mg} / \mathrm{kg}$ \\
Ferrous Sulphate & $471.50 \mathrm{mg} / \mathrm{kg}$ \\
Ash & $4.5 \%$
\end{tabular}

Table II. Composition of Krebs Henseleit Solution (per litre)

\begin{tabular}{l|c}
\hline $\mathrm{NaHCO}_{3}$ & $2.10 \mathrm{~g}$ \\
$\mathrm{NaCl}$ & $6.90 \mathrm{~g}$ \\
$\mathrm{KCl}$ & $0.35 \mathrm{~g}$ \\
$\mathrm{KH}_{2} \mathrm{PO}_{4}$ & $0.16 \mathrm{~g}$ \\
$\mathrm{MgSO}_{4}$ & $0.30 \mathrm{~g}$ \\
$\mathrm{CaCl}_{2} \cdot 2 \mathrm{H}_{2} \mathrm{O}$ & $0.36 \mathrm{~g}$ \\
Glucose & $2.22 \mathrm{~g}$
\end{tabular}




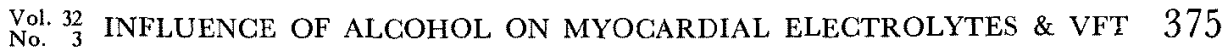

Rats were killed in pairs chosen at random from each group so that cardiac irritability and tissue mincral levels could be measured in matched animals. Rats were anesthetized with ether, given intravenous heparin $0.1 \mathrm{ml}$ (5000 I.U.), and killed by severing the aorta at thoracotomy. In one of each pair, the heart was rapidly excised and placed in ice-cold Krebs Henseleit solution (Table II) before mounting on the Langendorff apparatus for continuous cardiac perfusion. The heart of the other rat was frozen immediately after excision and stored at $-20^{\circ} \mathrm{C}$ to provide material for subsequent measurement of electrolytes.

\section{Ventricular Fibrillation Threshold:}

The excised heart used in the Langendorff preparation was perfused continuously with Krebs Henseleit solution, maintained at $37^{\circ} \mathrm{C}$ and aerated with $95 \% \mathrm{O}_{2}$ and $5 \% \mathrm{CO}_{2}$. After a stabilization period of $15 \mathrm{~min}$, measurement of heart rate began; a universal digital counter or a storage oscilloscope was used for this purpose. Coronary flow was measured by collecting the outflow of the heating chamber below the heart into a graduated measuring cylinder. The ventricular fibrillation threshold (VFT) was measured in the isolated heart using established techniques. ${ }^{10}$ ) A bipolar electrocardiograph (ECG) was recorded continuously from two pairs of platinum electrodes, about $1 \mathrm{~cm}$ apart, and displayed on an oscilloscope monitoring screen. The ECG was also recorded on a tape recorder and a photosensitive paper recording machine at 25,50 or $100 \mathrm{~mm} / \mathrm{sec}$. One electrode was attached to the metal aortic perfusion cannula. The other electrode was a very thin and flexible insulated copper wire, inserted into the epicardium of the anterior surface of the left ventricle. The site of insertion was at the midpoint between the base and the apex in a zone free of coronary artery branches. Two similar electrodes were inserted as stimulating electrodes. The cathode was placed just under the atrioventricular groove, close to the interventricular septum, while the anode was inserted at the apex of the diaphragmatic wall of the left ventricle. Ventricular fibrillation was defined as a rapid, repetitive, irregular ventricular rhythm with changing morphology which persisted for more than six cycles. To determine VFT, $200 \mathrm{~ms}$ pulse trains $(10 \mathrm{~ms}$ delays, $2 \mathrm{~ms}$ width at $60 \mathrm{~Hz}$ ) of increasing current intensity were applied at 30 sec delay intervals during the vulnerable period of the cardiac cycle until cardiac fibrillation occurred. Accurate positioning of stimulus and control of its sequence were achieved by an integrated control attached to a Grass stimulator. The procedure was repeated 3 times and the mean taken to represent VFT. 
Measurement of $\mathrm{Mg}^{2+}, Z^{2+}$ and $\mathrm{Na}^{+}$:

Excised hearts were placed in a $100 \mathrm{ml}$ beaker containing $5 \mathrm{ml}$ of $55 \%$ nitric acid. The beaker was put in a boiling water bath and digestion allowed to proceed until the heart was completely dissolved. A second beaker containing $10 \mathrm{ml}$ of $60 \%$ perchloric acid was placed on a sand bath in a specialized fume cupboard. A safety visor was provided to the analyst because of the explosive nature of perchloric acid. Anti-bumping granules were added and the perchloric acid allowed to come to a boil slowly. The nitric acid solution was added drop-wise to the boiling perchloric acid and the reaction continued until dryness. ${ }^{11,12)}$ Distilled water was added to the cooled beaker to a volume of $10 \mathrm{ml}$ and the solution stored at $-20^{\circ} \mathrm{C}$ for subsequent analysis. All chemicals used wore analytical grade. Tissue $\mathrm{Mg}^{2+}$ and $\mathrm{Zn}^{2+}$ levels were analyzed with an atomic absorption spectrophotometer (1275 Varian Model). The most common interference in air acetylene flame of $\mathrm{Mg}^{2+}$ analysis was overcome by the addition of lanthanum chloride $(10000 \mu \mathrm{g} / \mathrm{ml})$. No interference has been found in an air acetylene flame for $\mathrm{Zn}^{2+}$ analysis; $\mathrm{Na}^{+}$and $\mathrm{K}^{+}$were assayed by an IL 943 flame photometer using a cesium chloride, $1.5 \mathrm{mmol} / \mathrm{l}$ internal standard.

Statistical analysis of the results was carried out using the Mann Whitney Rank sum test, with a $\mathrm{p}$ value of 0.05 being accepted as the limit of significance for both VFT and heart tissue electrolytes.

\section{Results}

After 3 and 9 months of alcohol consumption the rats appeared healthy and not visibly different from control animals. Both groups gained weight. The excised hearts appeared normal macroscopically and their weights in the acute alcohol intake group $(1.08 \pm 0.05 \mathrm{~g} ; \mathrm{n}=10)$ and the chronic alcohol intake group $(1.12 \pm 0.03 \mathrm{~g} ; \mathrm{n}=10)$ did not differ significantly from controls $(0.98 \pm 0.01 \mathrm{~g} ; \mathrm{n}=10)$. Detailed results appear in Tables III and IV. Concentrations of $\mathrm{Mg}^{2+}, \mathrm{Zn}^{2+}$ and $\mathrm{K}+$ fell significantly in the hearts of both groups

Table III. Effect of Dietary Ethanol Supplementation on Concentrations of Several Elements $(\mu \mathrm{g} / \mathrm{g})$ in Rat Hearts

\begin{tabular}{l|c|c|c|c}
\hline Group & $\mathrm{Na}^{+}$ & $\mathrm{K}^{+}$ & $\mathrm{Mg}^{2+}$ & $\mathrm{Zn}^{2+}$ \\
\hline Control & $819(96)$ & $3260(437)$ & $233(28)$ & $32.7(6.8)$ \\
Ethanol : 3 months & $1556(375)^{*}$ & $1779(312)^{*}$ & $148(23)^{*}$ & $14.0(4.0)^{*}$ \\
Ethanol : 9 months & $739(398)$ & $1195(205)^{*}$ & $107(15)^{*}$ & $4.2(3.4)^{*}$ \\
* p $<0.000 \mathrm{I} . \mathrm{n}=10$ in each group. & & & \\
Results expressed as mean \pm SEM.
\end{tabular}


Table IV. Effect of Dietary Ethanol Supplementation on Ventricular Fibrillation Threshold (VFT), Heart Rate (HR) and Coronary Flow (CF) of Rat Hearts

\begin{tabular}{l|c|c|c}
\hline Group & VFT (mA) & HR (beats min $\left.{ }^{-1}\right)$ & CF (ml/min) \\
\hline Control & $10.10(1.94)$ & $204(31)$ & $9.70(1.24)$ \\
Ethanol : 3 months & $8.30(4.04)$ & $193(18)$ & $10.02(1.83)$ \\
Ethanol : 9 months & $6.27(2.17)^{*}$ & $188(13)$ & $8.51(1.53)$ \\
$*$ p $<0.001 . \quad \mathrm{n}=10$ in each group. & & \\
Results expressed as mean \pm SEM.
\end{tabular}

of alcohol-fed rats. This change was more marked in the group which had the longest exposure to alcohol. Tissue $\mathrm{Na}^{+}$rose significantly after 3 months alcohol but this change was not maintained. VFT fell progressively and was significantly reduced after 9 months feeding with alcohol (Table IV). There was no change in coronary flow or heart rate in any group.

\section{Discussion}

In this experiment, all cations studied $\left(\mathrm{Mg}^{2+}, \mathrm{K}^{+}\right.$and $\left.\mathrm{Zn}^{2+}\right)$ were displaced down their respective electro-chemical gradients in the hearts of alcohol-fed rats. This was associated with an unequivocal fall in the ventricular fibrillation threshold. This increase in myocardial irritability was particularly marked in rats given alcohol for a period of 9 months. This result was consistent with the clinical finding that cardiac arrhythmias in patients depleted of magnesium by alcohol or furosemide respond favorably to treatment with magnesium salts. ${ }^{13), 14}$

Magnesium has an important role in the maintenance of normal cardiac excitability. Movement of this ion across cell membranes may occur more rapidly in the heart muscle than in other tissues, and the heart may therefore be the first organ to be affected by magnesium loss. Magnesium is an activator of many enzymes including $\mathrm{Na}, \mathrm{K}^{+}$-ATPase. The major function of this enzyme is to maintain proper ionic gradients across cell membranes which are important for controlling neural excitability and membrane transport systems. The loss of cellular magnesium results in reduction of $\mathrm{Mg}^{2+}$-ATP; this may affect the $\mathrm{Na}^{+}-\mathrm{K}^{+}$pump thereby altering membrane potential and consequently cardiac rhythm. Numerous clinical studies have shown that magnesium therapy may be effective in the management of cardiac arrhythmias. ${ }^{15), 16)}$

The roles played by $\mathrm{K}^{+}$and $\mathrm{Zn}^{2+}$ and alcohol per se also require comment. Potassium is often described as a principal cause of cardiac arrhythmias. Potassium is predominantly an intracellular ion and only about 
$2 \%$ of the body content is in the extracellular fluid. The very low extracellular concentration of potassium ions is important for normal neuromuscular activity and cardiac action. $\mathrm{Mg}^{2+}$ deficiency reduces the activity of $\mathrm{Na}^{+}$$\mathrm{K}^{+}$-ATPase, with a resultant reduction in the passage of extracellular $\mathrm{K}^{+}$ into the cell. Intracellular $\mathrm{K}^{+}$deficiency is associated with a decrease in resting membrane potential, which increases myocardial excitability. This has obvious relevance to the changes in VFT observed in the course of this study.

The significance of zinc deficiency within the myocardium is speculative at present. It is uncertain whether the lack of this ion, either alone or together with magnesium and potassium deficiency, has any influence upon myocardial excitability. Zinc frequently acts as an essential co-factor to enzymatic reactions and further insight into its effects upon VFT might be obtained by prolonged studies using diets selectively deficient in zinc.

The abuse of alcohol has been suggested as a risk factor in some forms of heart disease. ${ }^{17-21)}$ In view of the relatively long exposure to alcohol which took place in the present experiment, it is possible that significant alcohol-related changes took place in the rat myocardium. Samples were not subjected to microscopy. The findings of the present study reveal that changes in VFT and myocardial $\mathrm{Mg}^{2+}$ along with $\mathrm{K}^{+}$and $\mathrm{Zn}^{2+}$ might be correlated and that the VFT might be related to the intracellular activity of one or all of these substances. However, the changes in VFT were most marked in rats exposed to alcohol for the longest period. Thus, the possibility that the increase in myocardial electrical instability was a consequence of cellular damage due to alcohol per se, cannot be ruled out.

While our observations of increased myocardial electrical instability may be explicable on the basis of trace element deplction, other factors could be involved. We therefore are setting up further experiments in which alcohol-fed rats are to be given supplementary $\mathrm{Mg}^{2+}, \mathrm{K}+$ and $\mathrm{Zn}^{2+}$, to determine whether depletion of these elements is an important mechanism whereby alcohol induces morbid changes within the myocardium. This hypothesis is currently being evaluated in our laboratory.

\section{REFERENCES}

1. Loeb HS, Petras RJ, Gunnar RM, Tobin JR: Paroxysmal ventricular fibrillation in two patients with hypomagnesemia. Circulation 37:210, 1968

2. Iseri LT, Freed J, Bures AR: Magnesium deficiency and cardiac disorders. Am J Med 58: 837,1975

3. Sheehan J, White A: Diuretic-associated hypomagnesemia. Br Med J 285: 1157, 1982

4. Iseri LT, Chung P, Tobis J: Magnesium therapy for intractable ventricular tachyarrhythmias in normomagnesemic patients. West J Med 138: 823, 1983 
$\begin{array}{ll}\text { Vol. } 32 & \text { INFLUENCE OF ALCOHOL ON MYOCARDIAL ELECTROLYTES \& VFT } 379 \\ \text { No. } 3 & \text { VN }\end{array}$

5. Szekely $\mathbf{P}$, Wynne NA: The effect of magnesium on cardiac arrhythmias caused by digitalis. Clin Sci 10: 241, 1951

6. Tzivoni D, Keren A, Cohen AM, et al: Magnesium therapy for torsades de pointes. Am J Cardiol 53 : 528, 1984

7. Iseri LT, Fairshter RD, Hardemann JL, Brodsky MA: Magnesium and potassium therapy in multifocal atrial tachycardia. Am Heart J 110:789, 1985

8. De Carli C, Sprouse G, La Rosa JC: Serum magnesium levels in symptomatic atrial fibrillation and their relation to rhythm control by intravenous digoxin. Am J Cardiol 57: 956, 1986

9. Brautbar N, Altura BM: Hypophosphatemia and hypomagnesemia result in cardiovascular dysfunction: Theoretical basis for alcohol induced cellular injury. Alcoholism: Clin Exp Res $11: 118,1987$

10. Lubbe WF, Bricknell OL, Marzago C: Ventricular fibrillation thrcshold and vulnerable period in the isolated perfused rat heart. Card Vasc Res 9: 613, 1975

11. Syversen TLM, Syversen GB: A simple method for acid extraction of cadmium from tissue. Bull Enviro Cont Tox 13: 9, 1975

12. Monk RG: A procedure for complete and controlled oxidation of organic matter by perchloric acid. The Analyst 87: 64, 1962

13. Havestadt $\mathrm{C}$, Ising $\mathrm{H}$, Gunther $\mathrm{T}$, Feldman B, Schulter HJ: Electrolytes and ventricular arrhythmias. Magnesium 4: 29, 1985

14. Levin RM: The role of magnesium in cardiovascular disease. Card Vasc Res 10:37, 1985

15. Iseri LT: Magnesium in coronary artery disease. Drugs 28: 150, 1984

16. Altura BM, Altura BT: Magnesium and electrolytes transport and coronary vascular tone. Drugs 28: 120, 1984

17. Rubin E: Alcoholic myopathy in heart and skeletal muscle. New Engl J Med 301 : 28, 1979

18. Ehinger PO, Wu CF, De La Cruz JR, Weisse AB, Ahmed SS, Reagan TJ: Arrhythmias and "holiday heart" alcohol associated cardiac rhythm disorders. Am Heart J 95: 555, 1978

19. Buckingham TA, Kennedy HL, Goenyian AK, Vasilomanolakis EC, Shrirer KK, Sprague MK, Lyyski D: Cardiac arrhythmias in a population admitted to an acute alcohol detoxification centre. Am Heart J 110: 961,1985

20. Editorial: Dilated cardiomyopathy in Africa. Lancet i: 557, 1985

21. Editorial: Alcoholic heart disease. Lancet i: 961,1980 